\title{
Yeşil Muhasebe Farkındalığının Sosyal Sorumluluk Çerçevesinde Analizi: Çanakkale Onsekiz Mart Üniversitesi Örneği
}

\author{
Nurcan SÜKLÜM*
}

\section{ÖZET}

Çevre bilinci, sürdürülebilir çevre, yeşil üretim gibi konular günümüzde toplumun her kesimini ilgilendirir hale gelmiştir. Sosyal sorumluluk gereği, işletmelerin başta üretim olmak üzere gerçekleştirdikleri faaliyetleri dolayısıyla çevreye karşı daha dikkatli olmalarl gerekmektedir. İsletmeler, faaliyetleri sonucunda çevre üzerinde yarattıkları olumsuz etkileri yeşil muhasebe uygulamaları ile daha hassas bir şekilde takip etmektedirler. Yeşil muhasebe, işletmelerin faaliyetleri dolayısıyla çevre üzerinde yarattıkları olumsuzlukların muhasebe sistemine aktarılmasıdır. Bu araştırmanın amacı, muhasebe dersi alan öğrencilerin çevre bilinci ve yeşil muhasebe farkındalıklarının belirlenmesidir. Bu amaçla çalışmada anket yöntemi kullanılmış ve elde edilen veriler SPSS paket programı kullanılarak analiz edilmiştir. Analiz sonucunda öğrencilerin cinsiyetleri ve yeşil muhasebe farkındalıkları arasında anlamlı bir fark bulunmuştur. Yine öğrencilerin yeşil muhasebe hakkında bilgi sahibi olma durumu ile yeşil muhasebe farkındalı̆̆ arasında anlamlı bir fark bulunmuştur. Çalışmada diğer değişkenler ve yeşil muhasebe farkındalı̆̆ arasında kısmen anlamlı bir fark bulunmuştur.

Anahtar Kelimeler: Sosyal Sorumluluk, Yeşil Muhasebe, Çevre Muhasebesi.

JEL Sınıflandırması: M40,M41.

\section{Analysis Of Green Accounting Awareness On Social Responsibility: Çanakkale} Onsekiz Mart University Sample

\section{ABSTRACT}

Issues such as environmental awareness, sustainable environment and green production have become relevant to every part of society. In terms of social responsibility, businesses need to be more careful about the environment due to their activities, especially in production. As a result of their activities, businesses follow the negative impacts they create on the environment with green accounting practices more precisely. Green accounting is the transfer of the negativities that the businesses create on the environment due to their activities to the accounting system. The aim of this study is to determine the environmental awareness and green accounting awareness of the students taking accounting courses. For this purpose, the survey method was used and the data were analyzed by using SPSS package program. As a result of the analysis, there was a significant difference between the students' genders and green accounting awareness. Again, there was a significant difference between students' knowledge about green accounting and green accounting awareness. In the study, a significant difference was found between the other variables and green accounting awareness.

Keywords: Social Responsibility, Green Accounting, Environmental Accounting.

Jel Classification: M40,M41.

Makale Gönderim Tarihi: 08.02.2019

Makale Kabul Tarihi: 15.05.2019

Makale Türü: Araştırma Makalesi

\footnotetext{
* Dr. Öğr. Üyesi, Hitit Üniversitesi, Sungurlu Meslek Yüksekokulu, nurcansuklum@hitit.edu.tr, ORCIDD 00000002-3884-5450.
} 


\section{GİRIŞ}

İçinde bulunduğumuz çevrenin çeşitli nedenlerden dolayı tükenmeye başladığı bilinmektedir. Çevreyi korumak ve sürdürülebilirliği için bireysel olarak sosyal sorumluluk gereği her bireyin üzerine düşeni yapması gerekmektedir. Ancak bazen bu adımlar yetersiz kalmakta ve yasal önlemler alınmaktadır. İşletmeler de, çevreye üretim faaliyetlerinden kaynaklı zararlar verebilmekte ve bu zararları ortadan kaldırabilmek adına çeşitli önlemler almaktadırlar. Çevreyi korumak için yapılan faaliyetler muhasebeleştirilirken geleneksel muhasebe yetersiz kalmaktadır, bu yüzden bir uzmanlık muhasebesi olan yeşil muhasebe kapsamında takip edilmektedir. Bu noktada işletmelerde yeşil muhasebe uygulamalarını gerçekleştirecek meslek mensuplarının bu konuda gerekli bilgi ve hassasiyete sahip olmaları gerekmektedir. Ancak aktif olarak çalışan meslek mensupları kadar bu alanda eğitim alan üniversitelerin ilgili bölümlerindeki öğrencilerin de eğitimleri esnasında yeşil muhasebe hakkında bilgi ve farkındalığa sahip olmaları önemle üzerinde durulması gereken bir konudur. Bu kapsamda muhasebe alanında ara eleman ihtiyacını karşılama noktasında önemli bir payı olan önlisans öğrencilerinin eğitimleri esnasında yeşil muhasebe konusunda bilinçli olmalarının faydalı olacağı düşünülmektedir.

Buradan hareketle bu çalışmanın amacı muhasebe dersi alan öğrencilerin yeşil muhasebe hakkındaki algılarının ve farkındalıklarının belirlenmesidir. Bu amaçla Çanakkale Onsekiz Mart Üniversitesi Sosyal Bilimler Meslek Yüksekokulunda öğrenim gören öğrencilere anket uygulaması yapılmış ve elde edilen veriler SPSS paket programında analiz edilmiştir. Çalışmada frekans analizi, faktör analizi ve hipotez testi yapılmıştır. Çalışmanın hipotezleri non- parametrik testlerden Mann- Whitney U testi ve Kruskal- Wallis testi ile test edilmiştir.

Çalışmada öncelikle yeşil muhasebe hakkında teorik bilgi verilmiş, çalışma ile bağlantılı daha önce yapılmış çalışmalar incelenmiş ve son olarak araştırma bölümünde uygulama ile ilgili ayrıntılı bilgi verilmiştir.

\section{YEŞİL MUHASEBE KAVRAMI}

İşletmeler gerçekleştirdikleri faaliyetler nedeniyle içinde bulunduğu çevreyi hem etkilemekte hem de o çevreden etkilenmektedir. Dolayısıyla işletmelerin etki alanına giren tüm çevrelere karşı sorumlu oldukları açıktır (Terzi, 2013: 88). İşletmeler çevreye verdikleri zararları ortadan kaldırmak için çeşitli yöntemler kullanmakta, hammaddeleri daha verimli kullanmak, atıkları azaltmak, atık bertaraf yöntemlerini iyileştirmek ve çalışma koşullarını iyileştirmek için ürünlerini ve süreçlerini yenileyerek ve geliştirerek sürdürülebilir çevreye katkıda bulunmaktadırlar. Bunun için işletmelerin belirli maliyetlere katlanması gerekmektedir. Geleneksel muhasebe anlayışı, maliyetleri finansal bakış açısı ile değerlendirmekte, üretim ve tüketimin sosyal maliyetlerini dikkate almamaktadır. Buna karşılık çevre muhasebesi, çevre maliyetlerinin daha detaylı ve daha spesifik hesaplarda takip edilmesine olanak sağlamakta ve bu noktada yeşil muhasebe devreye girmektedir (İçöz ve Kılınç, 2016: 1517, KiranmaiandSwetha, 2018: 16). Yeşil muhasebe, sosyal sorumluluk gereği, işletmelerin çevre üzerindeki olumsuz etkilerinin belirlenmesi sonrasında ortaya çıkan bir uzmanlık muhasebesidir (Apalı, 2018: 39). Yeşil muhasebe, çevresel kaynakları ve bunlardaki değişiklikleri göz önünde bulunduran ve ülkenin sürdürülebilir kalkınması ve 
büyümesi için politika planlamak ve formüle etmek için bilgi tabanı sağlayan bir sistem olarak tanımlanabilmektedir (Jayanthı, 2015: 80).

EPA (United States Environmental Protection Agency) (1995), yeşil muhasebeyi makro düzeyde, finansal muhasebe düzeyinde ve yönetim muhasebesi düzeyinde olmak üzere 3 farklı boyutta tanımlamaktadır. Makro boyuttaki tanım, yenilenebilen ve yenilenemeyen ulusal doğal kaynakların tüketiminin ölçümüne dayanmaktadır. Finansal muhasebe boyutundaki tanımı, işletmelerin çevre ile ilgili bilgileri raporlaması ve ilgili taraflara iletmesi süreci ile ilgilidir. Yönetim muhasebesi düzeyinde ise, işletme ile ilgili hayati derecede önem taşıyan maliyetler, üretim süreci, planlama gibi konularla çevrenin bağlantısını incelemektedir.

Yeşil muhasebe, geleneksel ekonomik kalkınma hedefleri ile çevresel hedefler arasındaki farkları anlama ve yönetmeye yardımcı olma amacını taşımaktadır ( Rout, 2010: 47).

Sosyal sorumluluk kavramı kapsamında yeşil muhasebenin, çevresel sorumlulukların muhasebe sistemiyle bütünleștirilmesi, çevresel koşulların belirlenmesi, bunların olumsuz etkilerinin ortadan kaldırılmasına yönelik muhasebenin katkısının sağlanması, çevresel sorunların ortadan kaldırılmasına yönelik maliyet analizlerinin yapılması, çevresel kaynak envanterinin belirli bir zaman diliminde hangi düzeyde olduğunun saptanması gibi amaçları bulunmaktadır (Çelik, 2007: 154).

\section{LITERATÜR TARAMASI}

Yeşil muhasebe ile ilgili yapılan çalışmalar incelendiğinde bazı çalışmalarda yeşil muhasebe kavramı yerine çevre muhasebesi, ekolojik muhasebe gibi kavramların da kullanıldığı görülmüştür. Konuyla ilgili daha önce yapılmış çalışmalar incelenmiş ve aşağıda belirtilmiştir.

Kurşunel vd (2006), Konya ilinde faaliyet gösteren muhasebecilerin çevre muhasebesi konusundaki bilgi ve düşüncelerini araştırdıkları çalışmada, meslek mensuplarının hemen hemen yarısının çevre muhasebesi hakkında hiçbir bilgiye sahip olmadıklarını, ayrıca meslek mensuplarının çevresel bilgilerin mali tablolara yansıtılması gerektiğini düşündüklerini tespit etmişlerdir.

Otlu ve Kaya (2010), Elazığ il merkezindeki muhasebe meslek mensuplarının çevre muhasebesi hakkındaki düşüncelerinin tespit edilmesine yönelik yaptıkları çalışmada, muhasebecilerin çevre muhasebesi denilince çevresel bilgilerin muhasebe sistemine entegrasyonu ve çevresel maliyetlerin muhasebeleştirilmesini anladıklarını ve çevre muhasebesinin uygulanmasındaki en önemli amacın sürdürülebilir kalkınmanın sağlanması olduğunu tespit etmişlerdir. Çalışmada ayrıca muhasebe meslek mensuplarının çevre muhasebesinin temelinin sosyal sorumluluk kavramı olduğunu düşündükleri de tespit edilmiştir.

Kızıl vd. (2014) tarafından çevre muhasebesine verilen önemin tespit edilmesi amacıyla Yalova ilinde ikamet eden meslek mensubu serbest muhasebeci mali müşavirlere 
(SMMM) yönelik mülakat yöntemiyle yapılan çalışmada, çevre muhasebesinin öneminin arttığı ve bu hususta bilinç seviyesinin yükseldiği tespit edilmiştir.

Korukoğlu (2014), işletmelerin çevre muhasebesi konularına yaklaşımlarını araştırdıkları çalışmada, işletmelerin ilgili gruplara karşı olan sorumluluklarını yerine getirmede, uluslararası alanda rekabet güçlerini artırmalarında çevre muhasebesinin faydalı olduğunu/ olacağını düşündüklerini tespit etmişlerdir.

Aydın ve Gözütok (2015), Sivas ilinde faaliyet gösteren muhasebe meslek mensuplarının çevresel muhasebeye yönelik bilgi, düşünce ve algılarını belirlemek amacıyla yaptıkları çalışmada, muhasebe meslek mensuplarının yaklaşık olarak \%70'inin çevresel muhasebe hakkında bilgi sahibi olduğunu bu durumun da çevresel muhasebe açısından olumlu bir gelişme olduğunu tespit etmişlerdir.

A $\breve{g}$ (2017) tarafından Erzurum ve Erzincan illerinde faaliyet gösteren üretim işletmelerinin sosyal sorumluluk kavramı çerçevesinde çevre muhasebesine ve çevresel politikalara verdikleri önem düzeyinin tespit edilmesine yönelik yapılan çalışmada, işletmelerin faaliyet süreleri ve faaliyette bulundukları iller ile çevre muhasebesi ve çevresel politikalar arasında anlamlı ilişkiler tespit edilmiş olup özellikle Erzurum ilinde faaliyet gösteren kurumsal nitelikteki işletmelerin çevresel politikalara daha fazla önem verdiği tespit edilmiştir.

Yılmaz ve Şahin (2017), muhasebe dersi alan öğrencilerin yeşil muhasebe algılarını ölçmeye yönelik yaptıkları çalışmada, staj/iş tecrübesi olan öğrencilerin yeşil muhasebe konusundaki farkındalıklarının daha yüksek olduğu ve bankacılık ve sigortacılık bölümü öğrencilerinin çevre bilinci faktörüne verdikleri yanıtların diğer bölüm öğrencilerine göre daha düşük olduğu tespit etmişlerdir.

Egbunike ve Okoro (2018), Nijerya'da yeşil muhasebenin işletme karlılığı üzerindeki etkisini araştırdıkları çalışmada, yeşil muhasebe ile işletme karlılığı arasında anlamlı bir ilişki olmadığını tespit etmişlerdir.

Demirkol vd (2018) tarafından Şanlıurfa'da bulunan otel ve konukevlerinin çevre bilinci ve çevre muhasebesi ile ilgili tutumlarını ölçmeye yönelik yapılan çalışmada, işletmelerde çevre bilinç düzeyi arttıkça çevre muhasebesine verilen önemin de arttığı, ayrıca otel ve konukevi işletmelerinin yöneticilerinin cinsiyet, medeni durum, yaş, eğitim düzeyi ve faaliyet türüne göre çevreci bilinç düzeyleri ve çevre muhasebesine yönelik tutumları analiz edildiğinde bir farklılık olmadığı sonucuna ulaşılmıştır.

Literatürdeki çalışmalardan farklı olduğunu düşündüğümüz bu çalışmamızda, öğrencilerin cinsiyetleri ve yeşil muhasebe farkındalıkları arasında anlamlı bir ilişki bulunmuştur. Ayrıca öğrencilerin yeşil muhasebe hakkında bilgi sahibi olup olmama durumu ile öğrencilerin yeşil muhasebe farkındalığı arasında anlamlı bir ilişki elde edilmiş, diğer değişkenler ve yeşil muhasebe farkındalığı arasında ise kısmen anlamlı bir ilişki bulunmuştur. 


\section{MUHASEBE DERSI ALAN ÖĞRENCILLERIN SOSYAL SORUMLULUK KAPSAMINDA YEŞIL MUHASEBE FARKINDALIĞININ ARAŞTIRILMASI}

$\mathrm{Bu}$ bölüm, muhasebe dersi alan ön lisans öğrencilerinin yeşil muhasebe konusundaki farkındalıklarının tespit edilmesine yönelik araştırmanın amacı, yöntemi, araştırmanın bulguları ve yorumlanmasından oluşmaktadır.

\subsection{Araştırmanın Amacı ve Önemi}

Çevre bilinci, kişisel bazda olduğu kadar işletmeler ve ülke bazında da önemli olduğu için işletmeler de muhasebe işlemlerini yürütürken ve politikalarını belirlerken çevre bilinciyle hareket etmektedir. Dolayısıyla yeşil muhasebe dersleri muhasebe eğitiminde önemli bir yer teşkil etmektedir. Bu bağlamda çalışmanın amacı, muhasebe dersi alan ön lisans öğrencilerinin yeşil muhasebe hakkındaki farkındalıklarının ve bakış açılarının tespit edilmesidir.

\subsection{Araştırmanın Kapsamı ve Yöntemi}

Çalışmada, muhasebe dersi alan ön lisans öğrencilerinin yeşil muhasebe hakkındaki farkındalıklarının ve bakış açılarının tespit edilmesine yönelik veri toplamak amacıyla anket yöntemi kullanılmıştır. Anket formu Yılmaz ve Şahin (2017) tarafından yapılan çalışmadan uyarlanarak oluşturulmuştur. Anket öğrencilerin demografik faktörlerinin belirlenmesine yönelik ve yeşil muhasebeye bakış açılarının belirlenmesine yönelik olmak üzere iki bölümden oluşmakta ve toplamda 32 sorudan oluşmaktadır. Ankette yer alan sorular beşli Likert ölçeğine (1= kesinlikle katılmıyorum, 2= katılmıyorum, 3= emin değilim, 4= katılıyorum, 5= kesinlikle katılıyorum) göre hazırlanmıştır. Elde edilen veriler "SPSS 20.0" istatistiksel paket programı kullanılarak analiz edilmiştir.

Çalışma, Çanakkale Onsekiz Mart Üniversitesi, Çanakkale Sosyal Bilimler Meslek Yüksekokulunda bünyesinde 2018-2019 eğitim-öğretim yılı güz yarıyılında öğrenim gören öğrenciler üzerinde gerçekleştirilmiştir. Araştırmanın evrenini söz konusu Meslek Yüksekokulu bünyesinde muhasebe dersi alan İşletme Yönetimi Programı, Muhasebe ve Vergi Uygulamaları Programı, Büro Yönetimi ve Yönetici Asistanlığı Programı ve Yerel Yönetimler programında öğrenim gören toplam 598 öğrenci oluşturmaktadır. Çalışmada uygulanan anket gün içerisinde eğitim-öğretim hizmeti gören 487 öğrenci ile gerçekleştirilmiş ve evrenin \% 81,43'üne ulaşılmıştır. Çalışmada frekans analizi, faktör analizi ve hipotezlerin test edilmesi amaciyla Mann- Whitney U testi ile Kruskal- Wallis testi yapılmıştır.

\subsection{Analiz ve Bulgular}

\subsubsection{Güvenilirlik Analizi}

Anket verilerinin değerlendirilmesinde öncelikle güvenilirlik analizi yapılmış, daha sonra ankete katılanların demografik özelliklerinin belirlenmesi amacıyla frekans analizi yapılmış, ankete katılan öğrencilerin verdikleri cevaplar arasında anlamlı bir farklılık olup olmadığının belirlenmesine yönelik ise, Mann Whitney $U$ testi ve Kruskall Wallis testi yapılmıştır. 
Anket verilerine öncelikle güvenilirlik testi uygulanmıştır. Güvenilirlik analizi ile toplam skorların söz konusu olduğu Likert Q tipi vb. ölçeklerin güvenilirliğini belirleyen katsayılar hesaplanmakta ve ölçekte yer alan sorular arasındaki ilişkiler hakkında bilgi elde edilmektedir. Güvenilirlik analizinde kullanılan yöntemlerden birisi olan Alfa Modeli Yönteminde, ölçekte yer alan " $k$ " sorunun homojen bir yapı gösteren bir bütünü ifade edip etmediği araştırılır. Ağırlıklı standart değişim ortalamasıdır ve bir ölçekteki " $k$ " sorunun varyansları toplamının genel varyansa oranlanması ile elde edilir. O ile 1 arasında değer alan bu katsayı (Cronbach ) Alfa katsayısı olarak adlandırılır. Bu katsayının 1'e yakın değer alması ölçeğin güvenilir olduğunu göstermektedir (Kalayc1, 2010: 403, 405).

Tablo 1. Güvenilirlik Analizi

\begin{tabular}{|c|c|}
\hline Cronbach's Alpha & N of Items \\
\hline, 878 & 32 \\
\hline
\end{tabular}

Güvenilirlik testi sonucunda, muhasebe dersi alan ön lisans öğrencilerinin yeşil muhasebe hakkındaki farkındalıklarının ve bakış açılarının tespit edilmesine yönelik geliştirilen ölçeğin genel Cronbach's Alpha katsayısı 0,878 düzeyinde anlamlı bulunmuştur. $\mathrm{Bu}$ sonuca göre ölçeğin yüksek düzeyde güvenilir olduğu tespit edilmiştir.

\subsubsection{Frekans Analizi}

Muhasebe dersi alan ön lisans öğrencilerinin yeşil muhasebe hakkındaki farkındalıklarının ve bakış açılarının tespit edilmesine yönelik yapılan ankete katılan öğrencilerin demografik özelliklerinin belirlenmesine yönelik frekans analizi yapılmıştır.

Tablo 2. Ankete Katılan Öğrencilerin Demografik Özelliklerine yönelik Frekans Dağılımı

\begin{tabular}{|c|c|c|c|c|c|c|c|}
\hline & & Frekans & Yüzde & & & Frekans & Yüzde \\
\hline \multirow{3}{*}{ Cinsiyet } & Kadın & 248 & 50,9 & \multirow[b]{3}{*}{ Sinıf } & 1.sinif & 270 & 55,4 \\
\hline & Erkek & 239 & 49,1 & & $2 . \sin 1 f$ & 201 & 41,3 \\
\hline & 19 yaş altı & 178 & 36,6 & & 3.sinıf ve üzeri & 8 & 1,6 \\
\hline \multirow{3}{*}{ Yaş } & $20-21$ & 235 & 48,3 & \multirow[b]{3}{*}{ Ortalama } & 1,99 ve alt1 & 147 & 30,2 \\
\hline & $22-25$ & 62 & 12,7 & & 2,00 ve 2,99 aras 1 & 176 & 36,1 \\
\hline & 26 ve üzeri & 10 & 2,1 & & 3,00 ve üzeri & 23 & 4,7 \\
\hline \multirow{5}{*}{$\begin{array}{l}\text { Seçmeyi } \\
\text { Düşündüğü } \\
\text { nüz Meslek }\end{array}$} & Akademisyenlik & 30 & 6,2 & \multirow{2}{*}{$\begin{array}{l}\text { Öğrenim } \\
\text { Türü }\end{array}$} & Normal öğretim & 277 & 56,9 \\
\hline & Mali Müşavirlik & 102 & 20,9 & & İ́kinci Öğretim & 207 & 42,5 \\
\hline & Bankacılık & 18 & 3,7 & \multirow{3}{*}{$\begin{array}{l}\text { İş } \\
\text { Deneyimi } \\
\text { niz } \\
\text { Oldumu }\end{array}$} & Evet & 424 & 87,1 \\
\hline & $\begin{array}{l}\text { Özel Sektörde } \\
\text { İdare Görevi }\end{array}$ & 45 & 9,2 & & Hayır & 63 & 12,9 \\
\hline & Memurluk & 41 & 8,4 & & & & \\
\hline
\end{tabular}




\begin{tabular}{|c|c|c|c|c|c|c|c|}
\hline & $\begin{array}{l}\text { Devlet } \\
\text { Kurumlarında } \\
\text { Uzmanlık }\end{array}$ & 74 & 15,2 & \multirow{4}{*}{$\begin{array}{l}\text { İş } \\
\text { Deneyimi } \\
\text { Türü }\end{array}$} & Staj yaptım & 169 & 34,7 \\
\hline & \multirow[t]{3}{*}{ Diğer } & \multirow[t]{3}{*}{172} & \multirow[t]{3}{*}{35,3} & & Özel Sektör & 203 & 41,7 \\
\hline & & & & & Kamu Sektörü & 12 & 2,5 \\
\hline & & & & & Diğer & 46 & 9,4 \\
\hline \multirow{6}{*}{ Bölüm } & İşletme Yönetimi & 154 & 31,6 & \multirow{3}{*}{$\begin{array}{l}\text { Yeşil } \\
\text { Muhasebe } \\
\text { Hakkında } \\
\text { Bilginiz } \\
\text { Var mı }\end{array}$} & Evet & 54 & 11,1 \\
\hline & $\begin{array}{l}\text { Muhasebe ve } \\
\text { vergi } \\
\text { Uygulamaları }\end{array}$ & 157 & 32,2 & & Hayır & 402 & 82,5 \\
\hline & Yerel Yönetimler & 106 & 21,8 & & Kararsızım & 30 & 6,2 \\
\hline & \multirow{3}{*}{$\begin{array}{l}\text { Büro Yönetimi } \\
\text { ve Yönetici } \\
\text { Asistanlığ1 } \\
\text { Programı }\end{array}$} & \multirow[t]{3}{*}{69} & \multirow[t]{3}{*}{14,2} & \multirow{3}{*}{$\begin{array}{l}\text { Yeşil } \\
\text { Muhasebe } \\
\text { Hakkında } \\
\text { Edinilen } \\
\text { Bilgi türü }\end{array}$} & Eğitimim sırasında & 27 & 5,5 \\
\hline & & & & & $\begin{array}{l}\text { Makale, kitap, internet vb. } \\
\text { kaynaklardan okudum }\end{array}$ & 16 & 3,3 \\
\hline & & & & & Diğer & 27 & 5,5 \\
\hline
\end{tabular}

Yapılan anket çalışması sonucunda katılımcıların \% 50,9'unun kadın, \% 49,1'inin erkek olduğu tespit edilmiştir. Katılımcıların yaşlarına bakıldığında \% 36,6'sının 19 yaş ve altında, \%48,3'ünün 20- 21 yaş aralığında, \% 12,7'sinin 22- 25 yaş aralığında ve \%2,1'inin ise 26 yaş ve üzerinde olduğu tespit edilmiştir. Öğrencilerin \% 55,4'ünün birinci sınıf, \%\% 41,3'ünün ikinci sınıf, \% 1,6'sının ise beklemeli öğrenciler olması da bir başka sonuçtur. Çalışmanın bulgularından birisi de not ortalamaları açısından, öğrencilerin \% 30,2'sinin 1,99 ve altı ortalamaya, $\% 36,1$ 'inin 2,00 ve 2,99 arasinda ortalamaya, $\% 4,7$ 'sinin 3,00 ve üzeri ortalamaya sahip olduğudur. Öğrencilerin bölümleri açısından dağılıma bakıldığında \%32,2'sinin muhasebe ve vergi uygulamaları, \% 31,6'sının işletme yönetimi, \%21,8'inin yerel yönetimler ve \%14,2'sinin ise büro yönetimi ve yönetici asistanlığ programında okuduğu tespit edilmiştir. Öğrencilere seçmeyi düşündükleri meslek sorulmuş ve \% 20,9'u mali müşavirlik, \%15,2'si devlet kurumlarında uzmanlık, \%9,2'si özel sektörde idare görevi, \%8,4'ü memurluk, \%6,2'si akademisyenlik, \%3,7'si bankacılık, \%35,3'ü ise diğer şeklinde cevap vermiştir. Öğrencilerin \%87,1'i daha önceden bir iş deneyimine sahip olduklarını, $\% 12,9$ 'u ise herhangi bir iş deneyimine sahip olmadıklarını belirtmişlerdir. Öğrencilerin sahip oldukları iş deneyimi türü açısından verdikleri cevaplar incelendiğinde \% 41,7'sinin özel sektör, \%34,7'sinin staj, \%2,5'inin kamu sektörü deneyimi olduğu tespit edilmiş, \% 9,4'ünün ise diğer deneyim şeklinde yanıt verdiği tespit edilmiştir. Ankete katılan öğrencilerin \% $\% 2,5^{\prime} \mathrm{i}$ yeşil muhasebe hakkında bilgi sahibi olmadıklarını, \%11,1'i ise bilgi sahibi olduklarını belirtmişlerdir. \% 6,2'si ise kararsız olduklarını ifade etmişlerdir. Öğrencilerin \% 5,5'i yeşil muhasebe hakkındaki bilgiye eğitimleri esnasında sahip olduklarını, \%3,3'ü makale vb. kaynaklar aracılığı ile sahip olduklarını, \%5,5'i ise diğer kanallar aracılığı ile sahip olduklarını belirtmişlerdir. 
Tablo 3. Ankete Katılan Öğrencilerin Yeşil Muhasebe

Algılarına Yönelik Frekans Dağılımı

\begin{tabular}{|c|c|c|c|c|c|c|c|c|}
\hline İfadeler & Ortalama & $\begin{array}{l}\text { Standart } \\
\text { Sapma }\end{array}$ & $\mathbf{F}$ & 1 & 2 & 3 & 4 & 5 \\
\hline \multirow{2}{*}{ 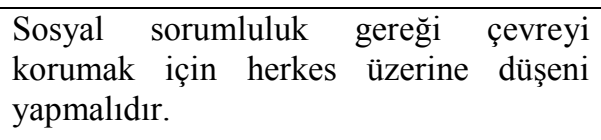 } & \multirow[t]{2}{*}{4,4867} & \multirow[t]{2}{*}{1,12552} & $\mathrm{~F}$ & 35 & 11 & 4 & 69 & 368 \\
\hline & & & $\%$ & 7,2 & 2,3 & 0,8 & 14,2 & 75,6 \\
\hline \multirow{2}{*}{$\begin{array}{l}\text { Çevreyi korumak için elektrik, su ve } \\
\text { yakıt tüketimini azaltmaya dikkat } \\
\text { ederim. }\end{array}$} & \multirow[t]{2}{*}{4,0431} & \multirow[t]{2}{*}{1,01033} & $\mathrm{~F}$ & 18 & 19 & 73 & 191 & 186 \\
\hline & & & $\%$ & 3,7 & 3,9 & 15,0 & 39,2 & 38,2 \\
\hline \multirow{2}{*}{$\begin{array}{l}\text { Etrafımdaki insanları çevreye } \text { zarar } \\
\text { vermemeleri konusunda uyarırım. }\end{array}$} & \multirow[t]{2}{*}{3,9835} & \multirow[t]{2}{*}{,99675 } & $\mathrm{F}$ & 15 & 30 & 64 & 214 & 161 \\
\hline & & & $\%$ & 3,1 & 6,2 & 13,1 & 43,9 & 33,1 \\
\hline \multirow{2}{*}{$\begin{array}{l}\text { Ürünler arasında seçim yaparken çevreye } \\
\text { en az zarar veren ürünü satın almayı } \\
\text { tercih ederim. }\end{array}$} & \multirow[t]{2}{*}{3,4050} & \multirow[t]{2}{*}{1,11142} & $\mathrm{~F}$ & 35 & 54 & 156 & 158 & 81 \\
\hline & & & $\%$ & 7,2 & 11,1 & 32,0 & 32,4 & 16,6 \\
\hline \multirow{2}{*}{$\begin{array}{lccc}\text { Çevreye } & \text { duyarlı ürünler } & \text { üretme } \\
\text { konusunda } & \text { işletmeler } & \text { finansal } & \text { olarak } \\
\text { desteklenmelidir. } & & \end{array}$} & \multirow[t]{2}{*}{4,2899} & \multirow[t]{2}{*}{,99315 } & $\mathrm{F}$ & 20 & 11 & 35 & 160 & 257 \\
\hline & & & $\%$ & 4,1 & 2,3 & 7,2 & 32,9 & 52,8 \\
\hline \multirow{2}{*}{$\begin{array}{l}\text { İşletmeler sosyal sorumluluk gereği } \\
\text { çevre ile ilgili } \\
\text { raporlamalıdır. }\end{array}$} & \multirow[t]{2}{*}{4,1491} & \multirow[t]{2}{*}{,92147 } & $\mathrm{F}$ & 12 & 14 & 60 & 201 & 196 \\
\hline & & & $\%$ & 2,5 & 2,9 & 12,3 & 41,3 & 40,2 \\
\hline \multirow{2}{*}{$\begin{array}{l}\text { Yeşil muhasebe uygulamalarının temiz } \\
\text { ve güvenli üretimi arttıracağına } \\
\text { inanıyorum. }\end{array}$} & \multirow[t]{2}{*}{3,6803} & \multirow[t]{2}{*}{,96315 } & $\mathrm{F}$ & 15 & 9 & 197 & 134 & 111 \\
\hline & & & $\%$ & 3,1 & 1,8 & 40,5 & 27,5 & 22,8 \\
\hline \multirow[b]{2}{*}{$\begin{array}{l}\text { Çevresel problemlerin } \\
\text { işletmelerin çümü için } \\
\text { uygulamalarını yürütmeleri gereklidir. }\end{array}$} & \multirow[t]{2}{*}{3,7323} & \multirow[t]{2}{*}{,91897 } & $\mathrm{F}$ & 9 & 15 & 177 & 157 & 109 \\
\hline & & & $\%$ & 1,8 & 3,1 & 36,3 & 32,2 & 22,4 \\
\hline \multirow{2}{*}{$\begin{array}{l}\text { Çevresel problemlerle ilgili yenilik ve } \\
\text { gelişmeleri güncel olarak takip ederim. }\end{array}$} & \multirow[t]{2}{*}{3,3182} & \multirow[t]{2}{*}{1,04654} & $\mathrm{~F}$ & 30 & 66 & 164 & 168 & 56 \\
\hline & & & $\%$ & 6,2 & 13,6 & 33,7 & 34,5 & 11,5 \\
\hline \multirow{2}{*}{$\begin{array}{l}\text { Yeşil muhasebe uygulamalarının doğal } \\
\text { kaynakların gereksiz tüketiminin } \\
\text { sinırlandırılmasında yararlı olacağına } \\
\text { inanıyorum. }\end{array}$} & \multirow[t]{2}{*}{3,7637} & \multirow[t]{2}{*}{,92594 } & $\mathrm{F}$ & 12 & 12 & 164 & 174 & 112 \\
\hline & & & $\%$ & 2,5 & 2,5 & 33,7 & 35,7 & 23,0 \\
\hline \multirow{2}{*}{$\begin{array}{llr}\text { İşletmelerin } & \text { yeşil } & \text { muhasebe } \\
\text { uygulamalarına katılmaları } & \text { sosyal } \\
\text { sorumluluk gereği devlet } & \text { tarafından } \\
\text { zorunlu hale getirilmelidir. } & \end{array}$} & 3,6751 & ,99040 & $\mathrm{F}$ & 15 & 23 & 175 & 149 & 112 \\
\hline & & & $\%$ & 3,1 & 4,7 & 35,9 & 30,6 & 23,0 \\
\hline İşletme ve çevre arasındaki ilişki yeşil & 3,5403 & ,89731 & $\mathrm{F}$ & 11 & 19 & 225 & 138 & 79 \\
\hline & & & $\%$ & 2,3 & 3,9 & 46,2 & 28,3 & 16,2 \\
\hline Yeşil muhasebe uygulamalarının & 3,6554 & 98164 & $\mathrm{F}$ & 18 & 12 & 193 & 142 & 108 \\
\hline ekosistemı koruyacağına ınanıyorum. & & & $\%$ & 3,7 & 2,5 & 39,6 & 29,2 & 22,2 \\
\hline
\end{tabular}




\begin{tabular}{|c|c|c|c|c|c|c|c|c|}
\hline \multirow{2}{*}{$\begin{array}{l}\text { İşletmeler yeşil } \quad \text { muhasebe } \\
\text { uygulamalarının bir parçası olarak çevre } \\
\text { politikalarını belirlemelidir. }\end{array}$} & \multirow[t]{2}{*}{3,7288} & \multirow[t]{2}{*}{,91842 } & $\mathrm{F}$ & 12 & 16 & 160 & 184 & 100 \\
\hline & & & $\%$ & 2,5 & 3,3 & 32,9 & 37,8 & 20,5 \\
\hline \multirow{2}{*}{$\begin{array}{l}\text { Yeşil muhasebe uygulamaları dolaylı } \\
\text { olarak işletmelerin maliyetlerinin } \\
\text { düşmesini sağlar. }\end{array}$} & \multirow[t]{2}{*}{3,5106} & \multirow[t]{2}{*}{1,04223} & $\mathrm{~F}$ & 24 & 28 & 198 & 124 & 96 \\
\hline & & & $\%$ & 4,9 & 5,7 & 40,7 & 25,5 & 19,7 \\
\hline \multirow{2}{*}{$\begin{array}{l}\text { Geri dönüşümlü ürünleri pahalı olsa da } \\
\text { alırım. }\end{array}$} & \multirow[t]{2}{*}{3,0888} & \multirow[t]{2}{*}{1,19971} & $\mathrm{~F}$ & 63 & 68 & 187 & 95 & 71 \\
\hline & & & $\%$ & 12,9 & 14,0 & 38,4 & 19,5 & 14,6 \\
\hline \multirow{2}{*}{$\begin{array}{l}\text { Yeşil muhasebe uygulamalarının üretim } \\
\text { sırasında ortaya çıkan } \\
\text { yönetiminde atıların } \\
\text { inanıyorum. }\end{array}$} & \multirow[t]{2}{*}{3,6730} & \multirow[t]{2}{*}{,95388 } & $\mathrm{F}$ & 14 & 18 & 178 & 159 & 102 \\
\hline & & & $\%$ & 2,9 & 3,7 & 36,6 & 32,6 & 20,9 \\
\hline \multirow{2}{*}{$\begin{array}{l}\text { Yeşil muhasebe uygulamalarının su } \\
\text { kullanımı ve yönetiminde yararlı } \\
\text { olacağına inanıyorum. }\end{array}$} & \multirow[t]{2}{*}{3,6723} & \multirow[t]{2}{*}{,91620 } & $\mathrm{F}$ & 12 & 19 & 172 & 179 & 91 \\
\hline & & & $\%$ & 2,5 & 3,9 & 35,3 & 36,8 & 18,7 \\
\hline \multirow{2}{*}{$\begin{array}{l}\text { Yeşil muhasebe uygulamalarının sera } \\
\text { gazı salınımını }(\mathrm{CO} 2) \text { yönetmekte yararlı } \\
\text { olacağına inanıyorum. }\end{array}$} & \multirow[t]{2}{*}{3,4926} & \multirow[t]{2}{*}{,94660 } & $\mathrm{F}$ & 20 & 18 & 220 & 142 & 75 \\
\hline & & & $\%$ & 4,1 & 3,7 & 45,2 & 29,2 & 15,4 \\
\hline \multirow{2}{*}{$\begin{array}{l}\text { Yeşil muhasebe uygulamalarının enerji } \\
\text { tasarrufunu artıracağına inanıyorum. }\end{array}$} & \multirow[t]{2}{*}{3,7061} & \multirow[t]{2}{*}{,95242 } & $\mathrm{F}$ & 14 & 19 & 163 & 173 & 104 \\
\hline & & & $\%$ & 2,9 & 3,9 & 33,5 & 35,5 & 21,4 \\
\hline \multirow{2}{*}{$\begin{array}{l}\text { Yeşil muhasebe, ayrı bir ders olarak } \\
\text { müfredatta yer almalıdır. }\end{array}$} & \multirow[t]{2}{*}{3,1747} & \multirow[t]{2}{*}{1,24312} & $\mathrm{~F}$ & 66 & 48 & 184 & 91 & 86 \\
\hline & & & $\%$ & 13,6 & 9,9 & 37,8 & 18,7 & 17,7 \\
\hline
\end{tabular}

Muhasebe dersi alan öğrencilerin, anketin ikinci kısmındaki yeşil muhasebeyle ilgili 21 ifadeye verdikleri yanıtların frekans analizi sonuçlarıTablo 3'de sunulmuştur. Tablo 3'e göre 4, 4867 ortalama ile en çok "sosyal sorumluluk gereği çevreyi korumak için herkes üzerine düşeni yapmalıdır" ifadesine katıldıkları görülmüştür. Bunu 4,2899 ortalama ile "çevreye duyarlı ürünler üretme konusunda işletmeler finansal olarak desteklenmelidir" ifadesi takip etmektedir. Öğrencilerin en çok katıldıkları üçüncü ifade ise, 4,1491 ortalama ile "işletmeler sosyal sorumluluk gereği çevre ile ilgili faaliyetlerini raporlamalıdır" ifadesi olmuştur. Öğrencilerin en çok bu üç ifadeye katılmaları ile ilgili olarak, öğrencilerin toplumun her kesiminin çevre bilincine sahip olması gerektiğini düşündükleri ve işletmelerin de bu konuda desteklenmesi gerektiğini düşündükleri söylenebilir.

Diğer taraftan öğrencilerin en az oranda katıldıkları ifade, 3,0888 ortalama ile"geri dönüşümlü ürünleri pahalı olsa da alırım" ifadesidir.Bunu sırayla 3,17 ortalama ile "yeşil muhasebe, ayrı bir ders olarak müfredatta yer almalıdır" ifadesi, 3,3182 ortalama ile "çevresel problemlerle ilgili yenilik ve gelişmeleri güncel olarak takip ederim" ifadesi, 3,4050 ortalama ile "ürünler arasında seçim yaparken çevreye en az zarar veren ürünü satın almayı tercih ederim" ifadesi izlemektedir. 


\subsubsection{Faktör Analizi}

Bir çalışmanın ölçeğinin faktör analizine uygun olup olmadığını ölçmek amacıyla kullanılan yöntemlerden birisi de "Kaiser- Meyer- Olkin (KMO) örneklem yeterliliği ölçütü" yöntemidir. Yönteme göre KMO oranının $(0,5)$ 'in üzerinde olması gerekmektedir. Bu oran ne kadar yüksek olursa çalışmanın faktör analizi yapmak için o kaday uygun olduğu anlamına gelmektedir (Kalayc1, 2010: 321, 322).

Çalışmada veri setinin faktör analizine uygun olup olmadığ 1 test edilmiş ve KaiserMeyer- Olkin (KMO) değeri 0, 935 bulunmuştur. Buradan anket sorularının faktör analizine uygun olduğu sonucuna ulaşılmış, daha sonra isimlendirilebilir ve yorumlanabilir faktörler elde etmek amaciyla yapılan rotasyon tekniklerinden biri olan direct oblimin rotasyonlu faktör analizi sonucunda 4 faktör belirlenmiştir. Faktör analizi sonuçları Tablo 4 'de belirtilmiştir.

Tablo 4. Açımlayıcı Faktör Analizi Sonuçları

\begin{tabular}{|c|c|c|c|c|}
\hline & \multicolumn{4}{|c|}{ Rotated Component Pattern Matrix } \\
\hline & $\mathrm{F} 1$ & $\mathrm{~F} 2$ & F3 & F4 \\
\hline Faktör 1: Yeşil Muhasebe Algısı & \multirow{2}{*}{,848 } & & & \\
\hline $\begin{array}{l}\text { Çevresel problemlerin çözümü için işletmelerin yeşil muhasebe } \\
\text { uygulamalarını yürütmeleri gereklidir (s.19) }\end{array}$ & & & & \\
\hline $\begin{array}{l}\text { Yeşil muhasebe uygulamalarının temiz ve güvenli üretimi arttıracağına } \\
\text { inanıyorum (s.18) }\end{array}$ &, 723 & & & \\
\hline $\begin{array}{l}\text { Yeşil muhasebe uygulamalarının doğal kaynakların gereksiz tüketiminin } \\
\text { Sınırlandırılmasında yararlı olacağına inanıyorum (s.21) }\end{array}$ & ,705 & & & \\
\hline $\begin{array}{l}\text { İşletmelerin yeşil muhasebe uygulamalarına katılmaları sosyal } \\
\text { sorumluluk gereği devlet tarafından zorunlu hale getirilmelidir (s.22) }\end{array}$ & ,669 & & & \\
\hline $\begin{array}{l}\text { İşletme ve çevre arasındaki ilişki yeşil muhasebe uygulamaları ile } \\
\text { raporlanır (s.23) }\end{array}$ &, 654 & & & \\
\hline $\begin{array}{l}\text { Yeşil muhasebe uygulamalarının ekosistemi koruyacağına inanıyorum } \\
\text { (s.24) }\end{array}$ &, 560 & & & \\
\hline Faktör 2: Çevre Bilinci & & \multirow[b]{2}{*}{, 889} & & \\
\hline $\begin{array}{l}\text { Sosyal sorumluluk gereği çevreyi korumak için herkes üzerine düşeni } \\
\text { yapmalıdır (s.12) }\end{array}$ & & & & \\
\hline $\begin{array}{l}\text { Çevreye duyarlı ürünler üretme konusunda işletmeler finansal olarak } \\
\text { desteklenmelidir (s.16) }\end{array}$ & &, 725 & & \\
\hline $\begin{array}{l}\text { İşletmeler sosyal sorumluluk gereği çevre ile ilgili faaliyetlerini } \\
\text { raporlamalıdır (s.17) }\end{array}$ & & 673 & & \\
\hline $\begin{array}{l}\text { Çevreyi korumak için elektrik, su ve yakıt tüketimini azaltmaya dikkat } \\
\text { ederim (s.13) }\end{array}$ & & ,661 & & \\
\hline $\begin{array}{l}\text { Etrafımdaki insanları çevreye zarar vermemeleri konusunda uyarırım } \\
\text { (s.14) }\end{array}$ & &, 549 & & \\
\hline
\end{tabular}




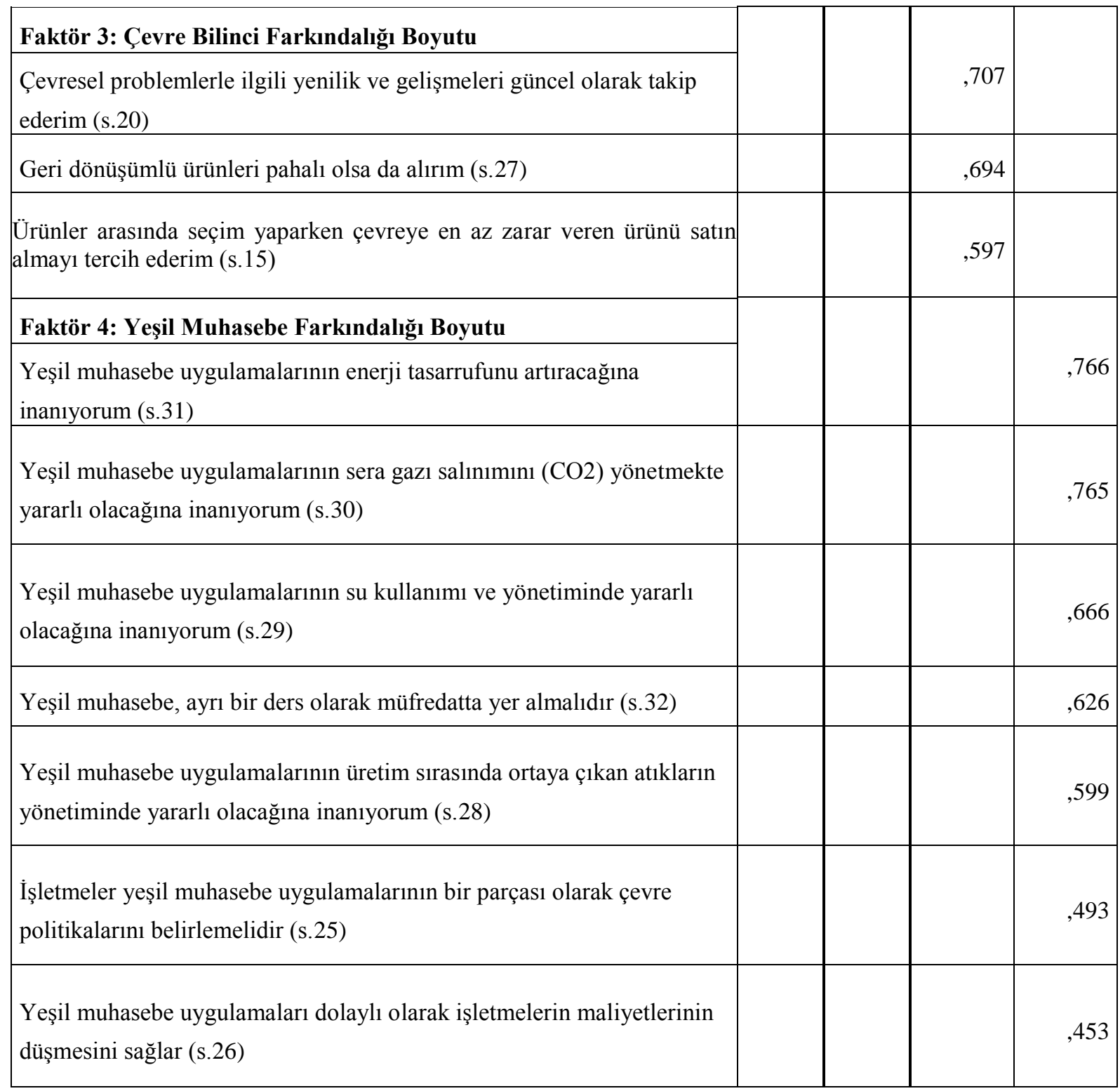

Not: 0,30 atındaki değerler gösterilmemiştir.

Yapılan faktör analizi sonucuna göre faktörlerin varyansları açıklama yüzdeleri Tablo 5'de belirtilmiştir. Tabloya göre faktörlerin toplam varyansı açıklama yüzdesi \%63, 654'dür. Varyansı açıklama yüzdesi en yüksek olan faktör \%8,810 değeri ile yeşil muhasebe algısı faktörüdür. Bunu sırasıyla çevre bilinci faktörü, çevre bilinci farkındalığı boyutu faktörü ve yeşil muhasebe farkındalığı boyutu faktörü izlemektedir. 
Tablo 5. Faktörlerin Varyansı Açıklama Yüzdeleri

\begin{tabular}{|c|c|c|c|}
\hline \multicolumn{3}{|c|}{ Total Variance Explained } \\
\hline \multirow{2}{*}{ Component } & \multicolumn{3}{|c|}{ ExtractionSums of SquaredLoadings } \\
\cline { 2 - 4 } & Total & \% of Variance & Cumulative \% \\
\hline F1 & 8,909 & 42,422 & 42,422 \\
\hline F2 & 1,850 & 8,810 & 51,231 \\
\hline F3 & 1,433 & 6,825 & 58,056 \\
\hline F4 & 1,176 & 5,598 & 63,654 \\
\hline
\end{tabular}

\subsubsection{Hipotez Testleri}

Ankete katılan öğrencilerin yeşil muhasebe algıları ile cinsiyet, yaş, kaçıncı sınıfta oldukları, ortalamaları, öğrenim türleri, bölümleri, iş deneyimleri ve türleri ve yeşil muhasebe hakkında daha önceden bilgi sahibi olma durumları arasında anlamlı bir farklılık olup olmadığı test edilmiştir. Hipotez testi yapılmadan önce veri setinin normal dağılımdan gelip gelmediği test edilmiştir.

Bir çalışmada parametrik analiz yapılabilmesi için verilerin aralıklı ya da oransal olması, verilerin normal dağılıma uyması (basıklık ve çarpıklık değerlerinin -1 ve +1 arasında olması) ve grup varyanslarının eşit olması gerekmektedir (Kalaycı, 2010: 73). Çalışmanın verileri parametrik analiz varsayımlarını taşımadığı için hipotezlerin test edilmesi için nonparametrik testlerden Mann- Whitney $U$ testi ile Kruskal- Wallis testi yapılmıştır. Bu kapsamda çalışmanın hipotezleri aşağıda belirtildiği gibidir.

\section{Öğrencilerin cinsiyetleri ile yeşil muhasebe farkındalığı arasındaki ilişki:}

Öğrencilerin yeşil muhasebe arasındaki farkındalıkları ile cinsiyet değişkenine ilişkin Mann-WhitneyUtesti sonuçları Tablo 6'da gösterilmiştir.

Tablo 6. Öğrencilerin yeşil muhasebe farkındalıkları ile cinsiyet değişkenine ilişkin Mann- Whitney Utesti sonuçları

\begin{tabular}{|c|c|c|c|c|c|c|c|}
\hline & Cinsiyet & $\mathbf{N}$ & $\begin{array}{l}\text { Sira } \\
\text { Ortalaması }\end{array}$ & $\begin{array}{l}\text { Sira } \\
\text { Toplamı }\end{array}$ & $\mathbf{U}$ & $\mathbf{Z}$ & $\mathbf{P}$ \\
\hline \multirow[t]{2}{*}{$\begin{array}{l}\text { Faktör 1: } \\
\text { Yeşil Muhasebe } \\
\text { Algis1 }\end{array}$} & Kadın & 245 & 252,14 & 61773,50 & \multirow[t]{2}{*}{25201,5} & \multirow[t]{2}{*}{$-2,147$} & \multirow[t]{2}{*}{0,032} \\
\hline & Erkek & 232 & 225,13 & 52229,50 & & & \\
\hline \multirow{2}{*}{$\begin{array}{l}\text { Faktör 2: } \\
\text { Çevre Bilinci }\end{array}$} & Kadın & 245 & 271,89 & 67429,5 & \multirow[t]{2}{*}{22718,5} & \multirow[t]{2}{*}{$-4,487$} & \multirow[t]{2}{*}{0,000} \\
\hline & Erkek & 232 & 215,06 & 51398,5 & & & \\
\hline $\begin{array}{l}\text { Faktör 3: } \\
\text { Çevre Bilinci } \\
\text { Farkındalı̆g } 1\end{array}$ & Kadın & 245 & 260,08 & 64501,00 & 25647,0 & $-2,589$ & 0,010 \\
\hline
\end{tabular}




\begin{tabular}{|l|l|l|l|l|l|l|l|}
\hline Boyutu & Erkek & 232 & 227,31 & 54327,00 & & & \\
\hline \begin{tabular}{l} 
Faktör 4: $\begin{array}{l}\text { Yeşil Muhasebe } \\
\text { Farkındalığ1 } \\
\text { Boyutu }\end{array}$ \\
\cline { 1 - 6 }
\end{tabular} & Kadın & 245 & 256,64 & 62876,00 & 23854,0 & -2975 & 0,003 \\
\cline { 2 - 5 } & Erkek & 232 & 219,26 & 50650,00 & & & \\
\hline
\end{tabular}

Tablo 6'da gösterilen Mann-Whitney U testi sonuçlarına göre, yeşil muhasebe farkındalığı ile cinsiyet değişkeni arasında anlamlı bir fark bulunmuştur. Erkeköğrencilere oranla kız öğrencilerin yeşil muhasebe farkındalığının daha yüksek olduğu tespit edilmiştir. $(\mathrm{p}<0,05)$.

\section{Öğrencilerin not ortalamaları ile yeşil muhasebe farkındalığı arasındaki ilişki:}

Öğrencilerin not ortalaması ile yeşil muhasebe farkındalıkları değişkenine ilişkin Kruskal- Wallis testi sonuçları Tablo 7'de gösterilmiştir.

Tablo 7. Öğrencilerin yeşil muhasebe farkındalıkları ile not ortalaması değişkenine ilişkin Kruskal- Wallis Utesti sonuçları

\begin{tabular}{|c|c|c|c|c|c|}
\hline & Not Ortalaması & $\mathbf{N}$ & $\begin{array}{l}\text { Sira } \\
\text { Ortalaması }\end{array}$ & Chi-Square & $\mathbf{P}$ \\
\hline \multirow[t]{3}{*}{$\begin{array}{l}\text { Faktör 2: } \\
\text { Çevre Bilinci }\end{array}$} & 1,99 ve altı ortalama & 147 & 154,32 & \multirow{3}{*}{13,497} & \multirow{3}{*}{0,001} \\
\hline & $2,00-2,99$ aras1 ortalama & 176 & 182,60 & & \\
\hline & 3,00 ve üzeri ortalama & 23 & 226,48 & & \\
\hline
\end{tabular}

Tablo 7'de gösterilen Kruskal- Wallis testi sonuçlarına göre, çevre bilinci faktörü ile not ortalaması değişkeni arasında anlamlı bir fark bulunmuştur. $(p<0,05)$. Çevre bilinci faktörünün,ortalama değeri3,00 ve üzeri olan öğrenciler üzerindedaha etkili olduğu tespit edilmiştir. Diğer faktörler ile akademik ortalama değişkeni arasında anlamlı bir fark bulunamamıştır.

\section{Öğrencilerin seçmeyi düşündükleri meslek ile yeşil muhasebe farkındalığı arasındaki ilişki:}

Öğrencilerin yeşil muhasebe farkındalıkları ile seçmeyi düşündükleri meslek değişkenine ilişkin Kruskal- Wallis testi sonuçları Tablo 8'de gösterilmiştir. 
Tablo 8. Öğrencilerin yeşil muhasebe farkındalıkları ile seçmeyi düşündükleri meslek değişkenine ilişkin Kruskal- Wallis testi sonuçları

\begin{tabular}{|c|c|c|c|c|c|}
\hline & $\begin{array}{ll}\text { Öğrencilerin } & \text { Seçmeyi } \\
\text { Düşündükleri Meslek } & \end{array}$ & $\mathbf{N}$ & $\begin{array}{l}\text { Sira } \\
\text { Ortalaması }\end{array}$ & Chi-Square & $\mathbf{P}$ \\
\hline \multirow{7}{*}{$\begin{array}{l}\text { Faktör 1: } \\
\text { Yeşil Muhasebe } \\
\text { Alg1sı }\end{array}$} & Akademisyenlik & 30 & 279,63 & \multirow{7}{*}{23,447} & \multirow{7}{*}{0,001} \\
\hline & Mali Müşavirlik & 101 & 266,00 & & \\
\hline & Bankacılık & 17 & 180,38 & & \\
\hline & Özel sektörde idare görevi & 43 & 220,49 & & \\
\hline & Devlet Kurumlarında Uzmanlık & 41 & 188,84 & & \\
\hline & Memurluk & 72 & 270,60 & & \\
\hline & Diğger & 169 & 219,36 & & \\
\hline
\end{tabular}

Tablo 8'de gösterilen Kruskal- Wallis testi sonuçlarına göre, yeşil muhasebe algısı faktörü ile öğrencilerin seçmeyi düşündükleri meslek değişkeni arasında anlamlı bir fark bulunmuştur. $(p<0,05)$. Yeşil muhasebe alg1sı faktörünün akademisyenlik mesleğini seçmeyi düşünen öğrenciler üzerinde daha etkiliolduğunu söylemek mümkündür. Ancak diğer faktörler ile öğrencilerin seçmeyi düşündükleri meslek değişkeni arasında anlamalı bir fark olmadığ 1 tespit edilmiştir.

Öğrencilerin herhangi bir iş deneyimi olup olmama durumu ile yeşil muhasebe farkındalığı arasındaki ilişki:

Öğrencilerin yeşil muhasebe farkındalıkları ile herhangi bir iş deneyimi olup olmama durumu değişkenine ilişkin Mann- Whitney U testi sonuçları Tablo 9'da gösterilmiştir.

Tablo 9. Öğrencilerin yeşil muhasebe farkındalıkları ile herhangi bir iş deneyimi olup olmama durumu değişkenine ilişkin Mann- Whitney U testi sonuçları

\begin{tabular}{|c|c|c|c|c|c|c|c|}
\hline & $\begin{array}{l}\text { Herhangi Bir } \text { İş } \\
\text { Deneyimi } \\
\text { Olmama Durumu }\end{array}$ & $\mathbf{N}$ & $\begin{array}{l}\text { Sira } \\
\text { Ortalaması }\end{array}$ & $\begin{array}{l}\text { Sira } \\
\text { Toplamı }\end{array}$ & $\mathbf{U}$ & $\mathbf{Z}$ & $\mathbf{P}$ \\
\hline \multirow[t]{2}{*}{$\begin{array}{l}\text { Faktör 2: } \\
\text { Çevre } \\
\text { Bilinci }\end{array}$} & Evet var & 414 & 249,39 & 105742,50 & \multirow[t]{2}{*}{11069,500} & \multirow[t]{2}{*}{$-2,209$} & \multirow[t]{2}{*}{0,027} \\
\hline & Hayır yok & 63 & 207,71 & 13085,50 & & & \\
\hline
\end{tabular}

Tablo 9' da gösterilen Mann- Whitney U testi sonuçlarına göre, çevre bilinci faktörü ile herhangi bir iş deneyimi olup olmama durumu değişkeni arasında anlamlı bir fark bulunmuştur. $(p<0,05)$.Çevre bilinci faktörünün daha önceden bir iş deneyimi olan öğrenciler üzerinde daha etkili olduğu sonucuna ulaşılmıştır. Test sonucuna göre diğer faktörler ile öğrencilerin iş deneyimi olup olmama değişkenini arasında anlamlı bir fark olmadığ görülmüştür. 
Öğrencilerin yeşil muhasebe hakkında bilgi sahibi olup olmama durumu ile yeşil muhasebe farkındalığı arasındaki ilişki:

Öğrencilerin yeşil muhasebe farkındalıkları ile yeşil muhasebe hakkında bilgi sahibi olup olmama durumu değişkenine ilişkin Kruskal- Wallis testi sonuçları Tablo 10'da gösterilmiştir.

Tablo 10. Öğrencilerin yeşil muhasebe farkındalıkları ile yeşil muhasebe hakkında bilgi sahibi olup olmama durumu değişkenine ilişkin Kruskal- Wallis testi sonuçları

\begin{tabular}{|c|c|c|c|c|c|}
\hline & $\begin{array}{l}\text { Yeşil Muhasebe Hakkında } \\
\text { Bilgi Sahibi Olup Olmama } \\
\text { Durumu }\end{array}$ & $\mathbf{N}$ & $\begin{array}{l}\text { Sira } \\
\text { Ortalaması }\end{array}$ & Chi-Square & $\mathbf{P}$ \\
\hline \multirow{3}{*}{$\begin{array}{l}\text { Faktör 1: } \\
\text { Yeşil Muhasebe } \\
\text { Alg1sı }\end{array}$} & Evet var & 54 & 347,84 & \multirow{3}{*}{41,452} & \multirow{3}{*}{0,000} \\
\hline & Hayır yok & 393 & 221,56 & & \\
\hline & Kararsızım & 29 & 264,52 & & \\
\hline \multirow{3}{*}{$\begin{array}{l}\text { Faktör 2: } \\
\text { Çevre Bilinci }\end{array}$} & Evet var & 54 & 326,63 & \multirow{3}{*}{22,162} & \multirow{3}{*}{0,000} \\
\hline & Hayır yok & 402 & 231,72 & & \\
\hline & Kararsızım & 30 & 251,77 & & \\
\hline \multirow{3}{*}{$\begin{array}{l}\text { Faktör 3: } \\
\text { Çevre Bilinci } \\
\text { Farkındalığ1 } \\
\text { Boyutu }\end{array}$} & Evet var & 54 & 283,96 & \multirow{3}{*}{5,130} & \multirow{3}{*}{0,077} \\
\hline & Hayır yok & 402 & 238,26 & & \\
\hline & Kararsızım & 30 & 240,90 & & \\
\hline \multirow{3}{*}{$\begin{array}{l}\text { Faktör 4: } \\
\text { Yeşil Muhasebe } \\
\text { Farkındalığ1 } \\
\text { Boyutu }\end{array}$} & Evet var & 54 & 317,10 & \multirow{3}{*}{22,586} & \multirow{3}{*}{0,000} \\
\hline & Hayır yok & 392 & 225,18 & & \\
\hline & Kararsızım & 29 & 264,05 & & \\
\hline
\end{tabular}

Tablo 10'da gösterilen Kruskal- Wallis testi sonuçlarına göre, yeşil muhasebe algısı faktörü, çevre bilinci faktörü ve yeşil muhasebe farkındalığı faktörü ile öğrencilerin yeşil muhasebe hakkında bilgi sahibi olup olmama durumu değişkeni arasında anlamlı bir fark bulunmuştur. $(p<0,05)$. Çevre bilinci farkındalığı faktörü ile öğrencilerin yeşil muhasebe hakkında bilgi sahibi olup olmama durumu arasında anlamlı bir fark bulunmamıştır. Test sonucuna göre yeşil muhasebe algısı faktörü, çevre bilinci faktörü ve yeşil muhasebe farkındalığı faktörünün yeşil muhasebe hakkında bilgi sahibi olan öğrenciler üzerinde daha etkili olduğu söylenebilir.

Öğrencilerin yeşil muhasebe hakkında ne şekilde bilgi sahibi oldukları ile yeşil muhasebe farkındalığı arasındaki ilişki:

Öğrencilerin yeşil muhasebe farkındalıkları ile yeşil muhasebe hakkında ne şekilde bilgi sahibi oldukları değişkenine ilişkin Kruskal- Wallis testi sonuçları Tablo 11'de gösterilmiştir. 
Tablo 11. Öğrencilerin yeşil muhasebe farkındalıkları ile yeşil muhasebe hakkında ne şekilde bilgi sahibi oldukları değişkenine ilişkin Kruskal- Wallis testi sonuçları Tablo 11'de gösterilmiştir.

\begin{tabular}{|l|l|r|r|l|l|}
\hline & $\begin{array}{l}\text { Yeşil Muhasebe Hakkında } \\
\text { ne şekilde bilgi sahibi } \\
\text { oldukları }\end{array}$ & N & $\begin{array}{l}\text { Sura } \\
\text { Ortalaması }\end{array}$ & Chi-Square & P \\
\hline $\begin{array}{l}\text { Faktör 2: } \\
\text { Çevre Bilinci }\end{array}$ & Eğitimim sırasında & 27 & 38,04 & \multirow{2}{*}{6,421} & \multirow{2}{*}{0,040} \\
\cline { 2 - 5 } & $\begin{array}{l}\text { Makale ve benzeri } \\
\text { kaynaklardan }\end{array}$ & 16 & 43,38 & & \\
\cline { 2 - 5 } & Diğer & 27 & 28,30 & \\
\hline
\end{tabular}

Tablo 11'de gösterilen Kruskal- Wallis testi sonuçlarına göre, çevre bilinci faktörü ile öğrencilerin yeşil muhasebe hakkında ne şekilde bilgi sahibi oldukları değişkeni arasında anlamlı bir fark bulunmuştur. $(\mathrm{p}<0,05)$. Test sonucuna göre çevre bilinci faktörünün makale ve benzeri kaynaklardan okuyarak yeşil muhasebe hakkında bilgi sahibi olan öğrenciler üzerinde daha etkili olduğu söylenebilir. Ancak diğer faktörler ile öğrencilerin yeşil muhasebe hakkında ne şekilde bilgi sahibi oldukları değişkeni arasında anlamlı bir fark bulunmamıştır.

\section{TARTIŞMA VE SONUÇ}

Çanakkale Onsekiz Mart Üniversitesi Çanakkale Sosyal Bilimler Meslek Yüksekokulu'nda muhasebe dersi alan öğrencilerin yeşil muhasebe farkındalığının araştırıldığı çalışmada katılımcıların çoğunluğunu kadın ve 20 ve 21 yaş aralığındaki öğrenciler ile 2,00 ve 2,99 arası not ortalamasına sahip olan öğrenciler oluşturmaktadır. Ankete katılan öğrencilerin çoğunluğu, sırasıyla mali müşavirlik ve devlet kurumlarında uzmanlık mesleğini seçmeyi düşündüklerini belirtmişlerdir.

Öğrencilere iş deneyimleri olup olmadığı sorulmuş ve çoğunluğu iş deneyimlerinin olduğunu ve en çok özel sektör deneyimi ve ikinci sırada staj deneyimleri olduğunu belirtmişlerdir. Öğrencilere sorulan bir başka soru yeşil muhasebe hakkında bilgi sahibi olup olmadıklarıdır ve ne yazık ki çoğunluğu bilgi sahibi olmadıklarını belirtmişlerdir. Ankete katılan öğrencilerin en çok önem verdikleri ifadeler sırasıyla "sosyal sorumluluk gereği çevreyi korumak için herkes üzerine düşeni yapmalıdır", "çevreye duyarlı ürünler üretme konusunda işletmeler finansal olarak desteklenmelidir", "işletmeler sosyal sorumluluk gereği çevre ile ilgili faaliyetlerini raporlamalıdır" ve "çevreyi korumak için elektrik, su ve yakıt tüketimini azaltmaya dikkat ederim" ifadeleri olmuştur.

Çalışmada öğrencilerin yeşil muhasebe farkındalıkları ile cinsiyet değişkeni arasında anlamlı bir fark bulunmuştur. Erkeklere kıyasla kadınların yeşil muhasebe farkındalığının daha yüksek olduğu tespit edilmiştir.

Çevre bilincinin, ortalaması 3,00 ve üzeri olan öğrenciler üzerinde daha yüksek olduğu tespit edilmiştir. Diğer faktörler ile not ortalaması değişkeni arasında anlamlı bir ilişki bulunamamıştır. 
Yeşil muhasebe algısının, akademisyenlik mesleğini seçmeyi düşünen öğrenciler üzerinde daha yüksek olduğunu söylemek mümkündür. Ancak diğer faktörler ile öğrencilerin seçmeyi düşündükleri meslek değişkeni arasında anlamalı bir ilişki olmadığı tespit edilmiştir.

Çevre bilincinin, daha önceden bir iş deneyimi olan öğrencilerde daha yüksek olduğu sonucuna ulaşılmıştır. Test sonucuna göre diğer faktörler ile öğrencilerin iş deneyimi olup olmama değişkenini arasında anlamlı bir ilişki olmadığı görülmüştür.

Yeşil muhasebe algısı, çevre bilinci ve yeşil muhasebe farkındalığı ile öğrencilerin yeşil muhasebe hakkında bilgi sahibi olup olmama durumu değişkeni arasında anlamlı bir ilişki bulunmuştur. Çevre bilinci farkındalığı ile öğrencilerin yeşil muhasebe hakkında bilgi sahibi olup olmama durumu arasında anlamlı bir ilişki bulunmamıştır. Yeşil muhasebe algısının, çevre bilinci ve yeşil muhasebe farkındalığının, yeşil muhasebe hakkında bilgi sahibi olan ögrencilerde daha etkili olduğu söylenebilir.

Test sonucuna göre çevre bilincinin, makale ve benzeri kaynaklardan okuyarak yeşil muhasebe hakkında bilgi sahibi olan öğrencilerde daha yüksek olduğu söylenebilir. Ancak diğer faktörler ile öğrencilerin yeşil muhasebe hakkında bilgi sahip oldukları araç türü değişkeni arasında anlamlı bir fark bulunmamıştır.

Sonuç olarak ankete katılan öğrencilerin büyük çoğunluğunun yeşil muhasebe hakkında bilgi sahibi olmadıkları ve farkındalık düzeylerinin düşük olduğu görülmüştür. $\mathrm{Bu}$ eksikliğin ortadan kaldırılabilmesi için muhasebe eğitimi alan öğrencilerin müfredatlarına yeşil muhasebe dersinin eklenmesi ya da ilgili muhasebe dersleri içerisinde bu konudan detaylı bir şeklide bahsedilmesinin etkili olacağı düşünülmektedir. Aynı şekilde çevreyi koruma bilincinin aşılanabilmesi için eğitimin ilk kademesinden son kademesine kadar çevre bilinci derslerinin verilmesi bu konuda atılacak önemli adımlardan birisi olacaktır.

\section{KAYNAKLAR}

A ğ, Alirıza (2017), “Çevre Muhasebesi ve Çevresel Politikalara Verilen Önem Düzeyi: Erzurum-Erzincan Karşılaştırması”, İstanbul Gelişim Üniversitesi Sosyal Bilimler Dergisi, Cilt 4, Say1 2, ss. 89- 105.

Apalı, Ali (2018), "Mermer Üretim İşletmelerinin Sosyal Sorumluluk Kavramı Kapsamında Çevre ve Çevre Muhasebesine Yaklaşımları: Bir Araştırma". Muhasebe ve Finansman Dergisi,Say1 78,ss. 37- 52.

Aydın, Yüksel- Gözütok, Esra (2015), "Sivas İlindeki Muhasebe Meslek Mensuplarının Çevresel Muhasebeye Yönelik Algılarının Ölçülmesi”, C.Ü. İktisadi ve İdari Bilimler Dergisi, Cilt 16, Sayı 2,ss. 239- 257.

Çelik, Muhsin (2007), "Çevreye Duyarlı Muhasebe", Muhasebe ve Finansman Dergisi, Sayı 33, ss. $151-161$.

Demirkol, Ömer Faruk- Tancı Yıldırım, Neslihan (2018), “Otel ve Konukevi İşletmelerinde Çevre Bilinci ve Çevre Muhasebesi Uygulama Düzeyi: Şanlıurfa İlinde Bir 
Araştırma”, Journal of CurrentResearches on Business andEconomics, Cilt 8, Sayı 1, ss. $27-40$.

Egbunike, AmaechiPatrick-Okoro,Godsday Edesiri (2018), "Does Green Accounting Matter To The Profitability Of Firms? A Canonical Assessment", Economic Horizons, Volume 20, Number 1.pp.15-23.

EPA (1995), “An Introduction to Environmental Accounting as a Business Management Tool: Key Concepts and Terms", Washington, D.C. 20460.

İçöz, Ahmet-Kılınç, Yavuz (2016), “Çevre Maliyetleri Muhasebesi Ve Raporlanması”, Uluslararası Sosyal Araştırmalar Dergisi, Cilt 9, Sayı 46, ss. 1517- 1530.

Jayanth1, R (2015), “Green Accountıng: A Study About Its Importance And Concept”, InternationalJournal Of ResearchIn Commerce \& Management, Volume 6, Issue11, pp. 76- 80 .

Kalaycı, Şeref (2010),SPSS Uygulamalı Çok Değişkenli İstatistik Teknikleri, Asil Yayın Dağıtım, 5. Baskı.

Kızıl, Cevdet- Akman, Vedat- Tasmacıoğlu, Abdulkadir - Taşkıran, Hakan (2014), "Çevre Muhasebesinin Önemi Üzerine Yalova İlinde Bir Araştırma”, Beykent Üniversitesi Sosyal Bilimler Dergisi, Cilt 7, Sayı 2, ss. 20- 34.

Kiranmai, J.,Swetha, C (2018), “Green Accounting Practices: An Overview”, The IUP Journal of Business Strategy, Vol 15, No 3,pp. 7- 18.

Korukoğlu, Ayşen (2014), "İ̧şletmelerin Çevre Muhasebesi Konularına Yaklaşımlarının Analizi”, Ege Akademik Bakış, Cilt 14, Sayı 3, ss. 481- 491.

Kurşunel, Fahri - Büyükşalvarcı, Ahmet - Alkan, Alper Tunga (2006), "Muhasebe Meslek Mensuplarının Çevre Muhasebesi Hakkındaki Görüşleri: Konya İli Üzerine Bir Araştırma”, Selçuk Üniversitesi Karaman İ.İ.B.F. Dergisi, Sayı 11, Y11 9, ss. 82- 88.

Otlu, Fikret- Kaya, Gamze Ayça (2010), "Çevre Muhasebesi İle İlgili Muhasebe Meslek Mensupları Üzerine Bir Araştırma”, Akademik Yaklaşımlar Dergisi, Cilt 1, Sayı 1, ss. 43- 56.

Rout, H. S(2010), “Green Accounting: Issues and Challenges”, The IUP Journal of Managerial Economics, Vol 8, No 3,pp. 46- 60.

Terzi, Ahmet (2013), "Sosyal Sorumluluk Açısından Çevre Muhasebesi Ve Çevre Muhasebesine Homo Ekonomikus Bir Bakış", Ordu Üniversitesi Sosyal Bilimler Enstitüsü Cilt 10, Sayı 12, ss. 86- 91.

Yılmaz, Züleyha - Şahin, Zeynep (2017), "Muhasebe Dersi Alan Öğrencilerin Yeşil Muhasebe Konusundaki Algıları ve Farkındalıkları”, Balkan ve Yakın Doğu Sosyal Bilimler Dergisi, Cilt 3, Say1 1, ss. 110- 122. 